\title{
https://doi.org/10.48009/2_iis_2006_252-256 \\ WHICH THEORY APPLIES: AN ANALYSIS OF INFORMATION SYSTEMS RESEARCH
}

\author{
Leila Halawi, Cookman College, halawil@ cookman.edu \\ Richard McCarthy, Quinnipiac University, Richard.mccarthy@quinnipiac.edu
}

\begin{abstract}
Research in information systems has rapidly expanded during its relatively brief existence. IT offers organizations a fundamental decisionenhancing environment that extends new opportunities, therefore producing thriving, competitive firms, adding business value and offering valuable products and services to customers. Research within the IT domain has produced several new theories, some of which have been used to help explain and predict end-user use of technologies. We provide a comprehensive overview of the major IT theories and review their theoretical fundamentals.
\end{abstract}

Keywords: Adaptive Structuration Theory, DeLone and McLean Information Success Model, Diffusion of Innovation Theory, Task Technology Fit, Technology Acceptance Model, Unified Theory of Acceptance and Use of Technology

\section{INTRODUCTION}

What distinguished societies in the preceding 200 years is the tendency of successive revolutions that shaped the way people earned their living and at the same time identified the essential utensils to attain power. Three eras are apparent. The agricultural era lasted through the late $1800 \mathrm{~s}$. The industrial era extended from the late 1800s until the early 1960s. The information era began in the 1960s [11]. This newest era has also been called the third wave [39], the digital economy [[38], the network economy [37], the knowledge-based economy [30], and the era of knowledge-based organizations [6].

Interest and writing in the field of information systems started in the late 1960s and grew throughout the 1970s. Through this age, educational institutions initiated degree programs in MIS along with its curriculum development. The emergence of conceptual material had immense implications throughout this time. Various perspectives on information systems demonstrate its study is a multidisciplinary field. No definite theory or perspective rules. The major disciplines that contribute include computer science, operations research, management science, sociology, economics, and psychology.

Our purpose is to identify the significant IT theories. We begin with a review of their theoretical fundamentals. We then highlight their importance and discuss their implications.

\section{CONCEPTUAL DEVELOPMENT}

The growth of the Internet, the globalization of trade, and the rise of information economies have raised the importance of information systems within organizations. It is imperative that researchers and practitioners recognize how information technologies shape the business world. The study of management information systems (MIS) appeared in the 1970s to concentrate on the use of computer-based information systems in business firms and government agencies [10].

There are a number of approaches to tackle the conceptual development of the MIS discipline. One is to emphasize those fundamental contributions to the MIS literature [4, 16, 26, 33]. A second approach investigates the growth and evolution of major MIS textbooks.

\section{Information Systems Theories}

The significant information systems theories include the following:

1. Structuration models explain how technological change influences organization design over time. Adaptive structuration theory (AST) is based on Gidden's structuration theory. DeSanctis and Poole [15] adapted Giddens' theory to investigate the interface between organizations and information systems. AST condemns the technocentric view of technology use and stresses the social aspects. AST is a feasible approach for examining the role of advanced information technologies in organization change. AST observes the change process from two ends: (1) the variety of structures that are presented by the advanced technologies and (2) the structures that surface as individuals interact with these technologies. The AST could be applied to examine 
the beginning of numerous innovations and demonstrate how the structures of these innovations invaded and impacted societies and how the social structures of those societies consecutively influenced and adapted the innovations' fundamental objectives.

2. DeLone and Mclean's model is viewed as a comprehensive IS assessment model [12, 29, 36] that is based on a review and integration of 180 research studies. In that study a comprehensive classification was introduced that provided six major categories of information systems success. The six major categories of IS success include (1) system quality, (2) information quality, (3) use, (4) user satisfaction, (5) individual impact, and (6) organizational impact [12]. Each of these variables is a composite of numerous and diverse constructs and measures. They argue that when measuring IS success, researchers should systematically combine measures from their six IS success categories. They also stress the need for additional research to test the model and for the selection of each IS success dimension. They present their results in terms of an IS Success Model as follows:

System quality and information quality impact both use and user satisfaction. The amount of use can affect user satisfaction positively or negatively. Use and user satisfaction are direct antecedents of individual impact which results in impact on the organization [12].

Several articles have been published which directly or indirectly validate, challenge, critique or extend the model itself [13]. Researchers such as Myers, Kappelman and Prybutok [29] have proposed modification to DeLone and McLean's IS success model to include service quality. The changes in the reformulated IS Success Model are largely changes in degree, not in the scope of the variables that comprise the model $[13,14]$.

3. Diffusion theory, initially developed for farming technologies, has been modified and utilized in several other disciplines and technologies, resulting in a technique that is methodologically and empirically mature [34]. Diffusion of Innovation theory (DIT) perceives innovations as being communicated through specific channels over time and within a particular social system. Rogers states, "diffusion is the process by which an innovation is communicated through a channel over time in a social system" [35, p. 5]. An innovation is an idea or item, which is perceived as new by the individual. Accordingly, a technological innovation is a new progress or mixture of material and non-material objects that result in a new item. Accordingly, Diffusion of Innovations identifies "four critical elements in the diffusion process: (a) the innovation, (b) its communication from one individual to another, (c) the social system, and (d) over time" [34, p.12]. Rogers [34, 35] presents the notion of adopter categories. Adopter categories are "the classifications of members in a social system on the basis of innovativeness" [35, p. 22]. These classifications include innovators (venturesome), early adopters (respect), early majority (deliberate), late majority (skeptical), and laggards (traditional). The rate of adoption of innovations is impacted by five factors: relative advantage, compatibility, trialibility, observability, and complexity [35]. Applying this concept, Rogers hypothesized that the innovativeness variable is normally distributed over time and the adopter categories divide the distribution by standard deviations from the average time. Conversely, Mahajan, Muller, and Srivastava [27] question this assumption of normality and state that there is no empirical evidence or validation on the size of the adopter categories being equal. Moore and Benbaset [28] expanded on the five factors, producing eight factors: voluntariness, relative advantage, compatibility, image, ease of use, result demonstrability, visibility, and trialibility that influence the adoption of IT.

4. The knowledge-based view of the firm [21, 22] builds upon and extends the resource-based theory of the firm initially promoted by Penrose [32] and expanded by others [1]. It discusses the facets to knowledge integration (efficiency, scope and flexibility) and the four primary mechanisms by which knowledge is coordinated (rules and directives, sequencing, routines and group problem solving and decision making). The knowledge-based perspective postulates that the services rendered by tangible resources depend on how they are combined and applied, which is in turn a function of the firm's know-how [1]. Knowledge-based resources are usually difficult to imitate and are socially complex; therefore, the knowledge-based view of the firm posits that these knowledge assets may produce longterm sustainable competitive advantage [1].

5. Goodhue and Thompson [20] postulated that for an information system to have a positive impact on individual performance, the technology should be exploited and must be a good fit with the task that it supports. Task-technology fit (TTF) offers a robust theoretical basis for a number of issues associated with the impact of information technology on individual performance, including recognizing the impact of user involvement on performance. TTF is 
an extension of two models that originated from social psychology: the theory of reasoned action (TRA), which hypothesizes that a person's behavior is determined by behavioral intentions, where intentions are a function of a person's attitude toward the behavior and containing the performance of the behavior, and the technology acceptance model (TAM). Task technology fit (TTF) is the degree to which a technology assists an individual in performing their tasks. Task technology fit [19] has been employed to offer the foundation for a user evaluation instrument aimed at an organizational evaluation of information systems exploitation for managerial decision making. Goodhue and Thompson [20] developed a measure of tasktechnology fit that consists of eight factors: quality, locatability, authorization to access data, compatibility, ease of use/training, production timeliness, systems reliability, and relationships with users. TTF has been employed in the context of a varied array of information systems embracing ecommerce systems and joined with or applied as an expansion of other models. TTF has undergone frequent adjustments to match the purposes of the specific study.

6. The technology acceptance model (TAM) [7, 8] is also an adaptation of the theory of reasoned action (TRA) [3, 7, 8]. TAM theorizes that user's perceptions of usefulness and ease of use are significant determinants of technology acceptance or adoption. The original TAM has since been expanded and is known today as TAM2. Davis [9] particularly recommends that additional external variables be applied to future research using TAM. TAM2 has been applied to explore end-user acceptance for adoption of a variety of information technology systems. TAM 2 has been used to describe and predict technology use in a number of different disciplines such as decisions sciences, management sciences, information technology and management information systems. TAM2 has also been employed to measure technology acceptance across several different cultures. TAM 2 clearly investigates and tackles the role of the end-user when new technology is initiated. It also facilitates the examination of additional and external forces.

7. The unified theory of acceptance and use of technology (UTAUT) seeks to clarify user intentions to use an IS and consequent usage behavior. The theory posits that four key constructs (performance expectancy, effort expectancy, social influence, and facilitating conditions) are direct determinants of usage behavior [40]. UTAUT offers a helpful means for managers to measure the chance of success of new technology initiations and assists them in recognizing the drivers of acceptance for them to propose interventions aimed at groups of users that could be less prone to embrace and utilize contemporary systems.

8. Nolan [31] proposed the stages theory, a set of concepts for understanding the absorption of IT in business organizations. It centers on the premise that nearly all organizations' computer expenditures formed an S-shaped curve over time, pursuing the common model of learning curves and experience curves. Given that organizational learning is somewhat the official transfer of recorded knowledge and in part the unofficial accrual of experiential knowledge, the theory suggests that every organization crosses four stages of learning sequentially: initiation, contagion, control and integration. Argyris and Schon [5] developed the theory of action perspective of organizational learning. They build on an earlier action research developed by Lewin in the 1940s with a focus on organizational learning. Argyris and Shon [5] postulated that comparable to individuals, organizations acquire a theory-in-use, which may or may not be reliable and attuned with the organization's theories adopted. According to Argyris and Shon [5], each member of an organization builds their personal depiction of the organizational theory-in-use and tries to appreciate and express themselves and their performance in the perspective of the organization. Accordingly, organizational learning is a four-step process that comprises discovery, invention, production, and generalization. Organizational learning is depicted as a process mediated by the collaborative inquiry of individual members, who constantly restructure the organizational theory-in-use.

\section{DISCUSSION}

The area of management information systems (MIS) is roughly thirty-five years young. The critical examination of the status of MIS began nearly two decades ago [2]. While progress has materialized in this area, our understanding of various issues remains obscure [23]. We have been witnessing intense discussions between MIS and non-MIS academics with regard to where MIS should be heading, what methods it should assume, and what areas of study should be used as its reference disciplines [17]. According to Khazanchi and Munkvold [24], the information systems (IS) discipline is apparently undergoing an identity crisis. Since the goal of our paper is neither to compare proposed frameworks nor to propose still another one, we have chosen to 
briefly outline the major IS theories. There are a number of good reasons for selecting this course. First, this would serve as a reference of many theories and would cover their main elements. Second, this article would shed light on the development of information systems. By defining the main components of each theory, this paper helps us explore and understand multiple features of IS and its environments.

Information systems are critical to individuals, organizations and society. Information systems research has expanded to include many diverse views of how technology is adopted, used and perceived by organizations and individuals. It has produced several significant theories, which have had significant follow-up research (for example, Table 1 identifies a count of the theories used in journal article research articles and citations within doctoral dissertations).

Table 1. IS Theory Research Summary

\begin{tabular}{|l|c|c|}
\hline Theories & $\begin{array}{l}\text { Dissertations } \\
\text { (UMI) }\end{array}$ & Articles \\
\hline Adaptive Structuration & 28 & 47 \\
\hline $\begin{array}{l}\text { Delone and McLean } \\
\text { Information Success } \\
\text { Model }\end{array}$ & 11 & 382 \\
\hline Diffusion of Innovation & 568 & 78 \\
\hline $\begin{array}{l}\text { Knowledge- Based } \\
\text { Theory of the Firm }\end{array}$ & 2 & 62 \\
\hline Task Technology Fit & 111 & 23 \\
\hline $\begin{array}{l}\text { Technology Acceptance } \\
\text { Model }\end{array}$ & 404 & 59 \\
\hline $\begin{array}{l}\text { Unified Theory of } \\
\text { Acceptance and Use }\end{array}$ & 1 & 1 \\
\hline $\begin{array}{l}\text { Stages Theory of IT } \\
\text { Adoption and } \\
\text { Organizational Learning }\end{array}$ & 10 & 15 \\
\hline
\end{tabular}

Information systems research has behavioral issues surrounding the development, use, and impact of information systems, which are also discussed in the fields of sociology, economics and psychology. The scope and variety of information systems research is so diverse that there is no single book source that attempts to link all of the theories into a cohesive unified presentation of information systems theory, though the authors acknowledge that the closest we come to this is the list of theories presented on the AIS website. We attempted a consolidated summary of the significant information systems theories in use today. It is significant because it provides a single source for future researchers to be able to see a unified view of these theories. This will serve the information systems community with a basic reference and draws their attention to the critical components of each theory.

In short, our experience as academics and practitioners leads us to deem that no one method efficiently describes the complexity of information systems. The successes and failures of information systems are hardly ever entirely technical or all behavioral so that several theories may have to be considered simultaneously when evaluating new technologies or significant changes to existing technologies.

\section{REFERENCES}

1. Alavi, M., \& Leidner, D. E. (2001). Review: Knowledge management and knowledge management systems: conceptual foundations and research issues. MIS Quarterly, 25(1), 107136.

2. Ackoff, R. (1967). Management information systems, Management Science, 14(4), 147-156.

3. Ajzen, I. \& Fishbein, M. (1980). Understanding Attitudes and Predicting Social Behavior. Englewoods Cliffs, NJ: Prentice-Hall, Inc.

4. Aron, J. (1969). Information systems in perspective. Computer Survey, 1(4), 213-236.

5. Argyris, C. \& Schon, D. (1978). Organizational Learning: A Theory of Action Perspective. Reading, MA: Addison-Wesley.

6. Clarke, T., \& Clegg, S. (1998). Changing Paradigms: The Transformation of Management Knowledge for the 21st Century. New York: Oxford University Press.

7. Davis, F. (1986). A technology acceptance model for empirically testing new end-user information system: theory and results, Doctoral Dissertation, Sloan School of Management, Massachusetts Institute of Technology.

8. Davis, F. (1989, Sep.). Perceived usefulness, perceived ease of use, and user acceptance of information technology, MIS Quarterly, 13(3), 319-340.

9. Davis, F. (1993). User acceptance of information technology: system characteristics, user perceptions and behavioral impacts. International Journal of Machine Studies, 38(3), 475-488.

10. Davis, G. \& Olson, M. (1985). Management Information Systems: Conceptual Foundations, Structure, and Development, 2nd Ed., New York: McGraw Hill.

11. Davenport, T. H., \& Prusak, L. (1998). Working Knowledge: How Organizations Manage What 
They Know. Boston: Harvard Business School Press.

12. DeLone, W. H., \& McLean , E. R. (1992). Information Systems Success: The Quest for the Dependent Variable. Information Systems Research, 3(1), 60-95.

13. DeLone, W. H., \& McLean, E. R. (2002, Jan.). Information Systems Success Revisited. Proceedings of the 35th Annual Hawaii International Conference on System Sciences, IEEE Computer Society, Hawaii, HI..

14. DeLone, W. H., \& McLean, E. R. (2003). The DeLone and McLean model of information systems success: A ten-year update. Journal of Management Information Systems, 19(4), 9-30.

15. DeSanctis, G. \& Poole, M. (1994, May). Capturing the complexity in advanced technology use: Adaptive structuration theory. Organization Science, 5(2), 121-147.

16. Dickson, G. (1968). Management information decision-systems. Business Horizon, Dec., $17-$ 26.

17. Farhoomand, A. (1987). Scientific progress of management information systems, Database, Summer, 48-56.

18. Giddens, A. (1984). The Constitution of Society: Outline of the Theory of Structuration. University of California Press, Berkeley, CA.

19. Goodhue, D. (1998). Development and measurement validity of a task-technology fit instrument for user evaluations of information systems. Decision Sciences, 29(1), 105-138.

20. Goodhue, D. \& Thompson, R. (1995, June). Task-technology fit and individual performance, MIS Quarterly, 19(2), 213-236.

21. Grant, R. M. (1996). Prospering in dynamicallycompetitive environments: organizational capability as knowledge integration. Organization Science, 7(4), 375-387.

22. Grant, R. (1995). A knowledge-based theory of inter-firm collaboration. Academy of Management Proceedings, 17-21.

23. Kendall, K. \& Kriebel, C. (1982). Contributions of the management sciences to the evolution of management information systems, Database, Fall, 13-18.

24. Khazanchi, D. \& Munkvold, B. (2000). Is information systems a science? An inquiry into the nature of the information systems discipline. The Database for Advances in Information Systems, 31(3), 24-42.
25. King, J. \& Kraemer, K. (1984). Evolution and organizational information systems: An assessment of nolan's stage model, Communications of the ACM, 27 (5), 466-475.

26. Kriebel C. (1972). The future of MIS, Infosystems, 19(6), 18-42.

27. Mahajan,V., Muller, E., \& Srivastava, R. K. (1990). Determination of adopter categories by using innovation diffusion models, Journal of Marketing Research, 27, 37-50.

28. Moore, G. C. \& Benbasat, I. (1991). Development of an instrument to measure the perceptions of adopting an information technology innovation. Information Systems Research, 2(3), 192-222.

29. Myers, B. L., Kappelman, L., \& Prybutok, V. R. (1997). A comprehensive model for assessing the quality and productivity of the information system function: toward a theory for information system assessment. Information Resources Management Journal, 10(1), 6-25.

30. Neef, D. (1998). The Knowledge Economy. Boston, MA: Butterworth-Heinemann.

31. Nolan, R. (1973, July). Stages hypothesis of computer growth. Communications of The ACM, 16(7), 399-405.

32. Penrose, E. T. (1959). The Theory of the Growth of the Firm. New York: Wiley.

33. Pounds, W. (1969). The process of problem finding. Ind. Manager Review, 11(1), 1-19.

34. Rogers, E. M. (1962). Diffusion of Innovations. New York: The Free Press of Glencoe.

35. Rogers, E. M. (1995). Diffusion of Innovations (4th Edition). New York: The Free Press.

36. Seddon, P. B. (1997). A respecification and extension of the DeLone and McLean Model of IS success. Information Systems Research, 8(3), 240-253.

37. Shapiro, C., \& Varian, H. R. (1999). Information Rules: A Strategic Guide To The Network Economy. Boston, MA: Harvard Business School Press.

38. Tapscott, D. (1996). The Digital Economy. New York, NY: McGraw Hill.

39. Toffler, A. (1980). The Third Wave. New York, NY: Morrow.

40. Venkatesh, V., Morris, M., Davis, G. \& Davis, F. (2003). User acceptance of information technology: Toward a unified view. MIS Quarterly, 27(3), 425-478. 